\title{
Kandinsky Inspired Digital Print Motive with Pattern-Making, Cutting Exploration of Edgy Looks for Ready to Wear Deluxe
}

\author{
Janet Rine Teowarang ${ }^{1}$ \\ ${ }^{1}$ Faculty of Creative Industry, Universitas Ciputra, Surabaya, Indonesia \\ janet.teowarang@ciputra.ac.id (Janet Rine Teowarang)
}

\begin{abstract}
The collaboration in between industry creative people will deliver strength in concept of design and creation for the result, as fashion industry is the largest and rising industry in Indonesia. Digital printing on textile is becoming trend development from few years ago, following emerging of international brand like Mary Katrantzou, Peter Pilotto and Jonathan Saunders were all started the digital bold prints with futuristic and cutting-edge theme in the year of 2010. As according to fashion trend report, Art-inspired prints have been dominating fashion runway with the appearance of neon colors and shall stay all the way in the year of 2017. The research theme of artistic digital print has brought the creative director's aim for exploration project of fashion collaboration between a fashion brand and graphic designer for creating art-inspired print by using digital printing with combination of pattern making exploration, the paintings of Wassily Kandinsky during his period at Bauhaus in 1922 until 1933, Kandinsky's Composition VIII and Transverse Lines during year 1923 had inspired the creative director to achieve variation of prints from combination, where finally this collaborative project has delivered into fashion showcase at fashion week in year of 2016 by using edgy and semi Avant-garde pattern making and cutting exploration into collection of Ready to Wear Deluxe consist of six looks varied from two - pieces top and bottom to long dress.
\end{abstract}

Keywords Art Inspired Print, Digital Printing, Creative Industry Collaboration, Edgy, Semi Avant-Garde, Pattern-Making Exploration

\section{Introduction}

The importance of collaboration in between creative industry people is prominent, since there will be innovative, artistic, and competitive result especially in fashion industry. In Indonesia, fashion industry is one of the largest industries, and it has been growing every year and even supported Indonesian economy. From statistic data and survey result from Indonesian creative economy, the growth of gross domestic product of creative economy from year of 2010 until 2015, the scale of gross domestic product from 535,96 trillion IDR rising into 852,24 trillion IDR, where increased about $10,14 \%$ per year, the value has given contribution to national economy dominated by three sub sectors which are culinary, fashion and craft. Fashion is the number two largest contribution of gross domestic product of creative economy at $18,15 \%$ beside Culinary at $41,69 \%$ as the first and Craft at $15,70 \%$ as the third. The main analysis of this research is to review the exploration of digital printing into fashion collection, as this is one of creative industry collaboration, where the digital print derived from art inspired motive into digital print on textile with further explore upon cutting and pattern making.

\section{Literature and Theory}

As following from research of study, "the use of digital print has rapidly established itself within fashion and textile design, although due to its high production costs, the major creative developments are to be found in the mid to high end of the fashion and textile design industry" (Bowles and Isaac, 2009). Digital print textile has influenced fashion industry strongly when many international fashion designers emerged with digital bold prints with futuristic and cutting-edge theme from Mary Katrantzou, Peter Pilotto, and Jonathan Saunders. 
At contemporary period, digital print motive has shifted into variety of inspiration, as from trend forecasting at fashion snoops of spring summer 2017 period, art inspired movement from Bauhaus has strongly influenced the season, where the artists such as Frank Stella and Auguste Herbin have inspired geometrical abstract patterns from their art movement span through cubism, abstract, minimalism and post - painterly abstraction. In addition, the statement for trend benchmarking enhancement, "There was an artistically inspired theme across the runways, from Roksanda and Céline to J.W. Anderson, Proenza Schouler, Marni, Valentino, and many other brands, whether directly inspired by a particular artist's work, painterly prints, or patterns, strong art references will be here to stay in 2017" (Foley, 2016). Another interesting issue about digital print textile when the technology of digital textile printing is used for developing apparel collection, giving its impact for creating new and novel products for creative expression as the role of digital tools evolving rapidly for current design process as studied by Parsons and Campbell in 2004.

\section{Data and Methods}

The explorative project has aimed achieving contemporary, advanced and fashionable result from identification problems, where digital textile print has been growing rapidly, therefore, should gather the research data in order to achieve further innovative range upon the pattern motive in combination with application of pattern making exploration. The creative director's aim for collaboration in between fashion brand and graphic designer by using trend benchmarking of art inspired motive, where the ideas of geometric abstract patterns into digital textile print motive. The concept of ideas from trend forecasting, Bauhaus had inspired creative director for using one of Staatliches Bauhaus's painter from Russia, Wassily Kandinsky at Weimar site, in which, has taken few of the work of Kandinsky's Composition VIII and Transverse Lines during year 1923 as the main ideas for creating motive on digital textile print with a characteristic from graphic designer in order to indicate the designer's signature. Creative director has made 12 looks of Ready to Wear Deluxe capsule collection for the project with title of collection Realm of Abstract, there are 6 looks from the collection have used digital textile print motif range from top and bottom such as skirt and pants, also short and long dresses. The print motifs are based on two basic colours on background, since geometrics abstract are mainly variety in colours; there are three designs of print motifs for 6 looks. The process of digital textile printing had taken 2 weeks at digital textile printing company in Jakarta after the designs are carefully created for certain area according to pattern making allocations, afterward; steps of pattern making exploration based from creative director's design on collection looks discover some new shapes of collars, pleats, cutting, and silhouette, where these things has led to semi Avant garde, and edgy style. Production process have used neat finishing techniques on sewing, and international standardization of chosen textile such as Cotton Jacquards, Silk Organza, Italian Cotton, Cotton Lawn for lining, also thorough quality control processing upon the garments.

\section{Figures and Tables}

There are geometrical abstract design motifs alongside process of digital textile printing at figure one until four; the designs are created on computer with software, later digitally printed on textile by using Satin Velvet, 100\% Satin Polyester fabric with after print finished width $144 \mathrm{~cm}$, approximate shrink percentage 0,5 until $1 \%$. There are three designs used for 6 looks from the collection, each carefully placed according the areas following pattern cutting on pattern making.

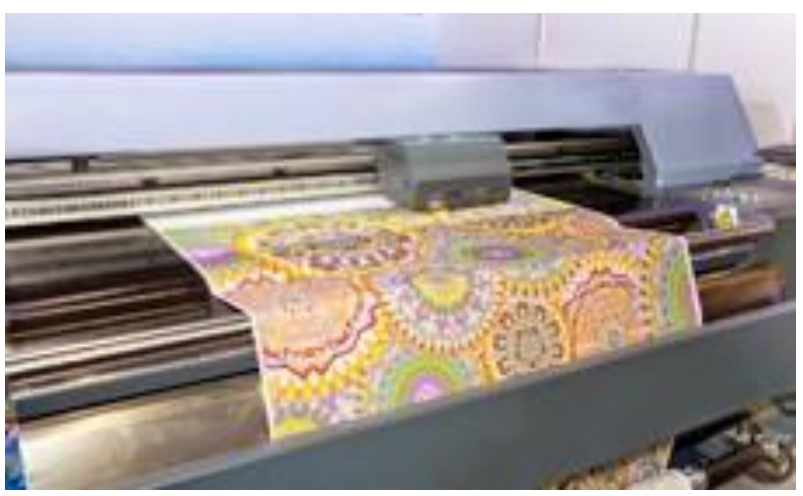

Figure 1. The printing process of digital textile print by Shrelo in Jakarta 


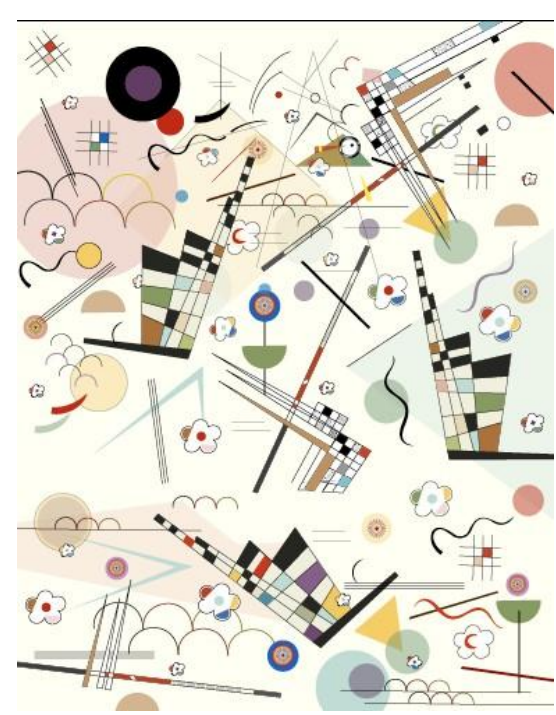

Figure 2. First Geometrical Abstract Design on Crème Background

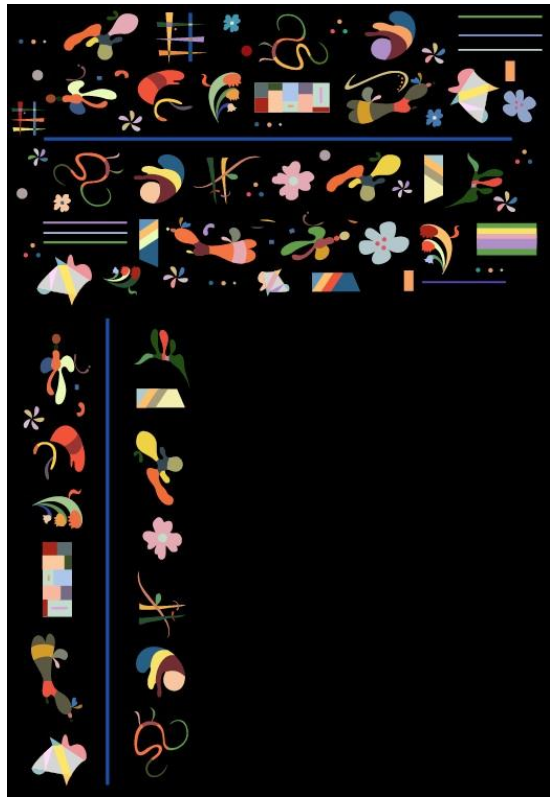

Figure 3. Second Geometrical Abstract Design on Black Background

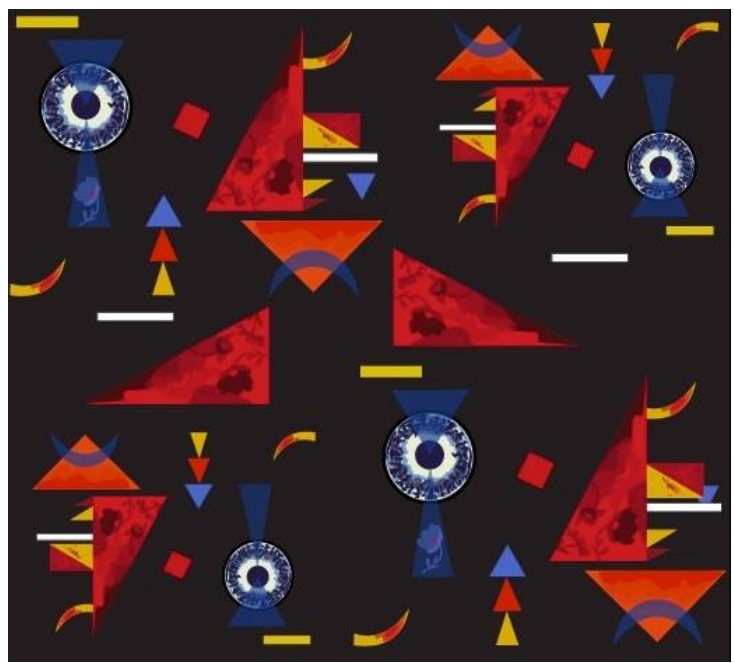

Figure 4. Third Geometrical Abstract Design on Black Background
Table 1. Design Placement on Collection

\begin{tabular}{|c|c|c|}
\hline $\begin{array}{l}\text { Type of Geometrical } \\
\text { Abstract Design Motif }\end{array}$ & $\begin{array}{c}\text { Area of } \\
\text { Placement }\end{array}$ & $\begin{array}{c}\text { Placement of } \\
\text { Digital Textile Print } \\
\text { Motif on Garment }\end{array}$ \\
\hline & $\begin{array}{c}\text { Front Bodice } \\
\text { Area }\end{array}$ & Sleeveless Top \\
\hline & $\begin{array}{c}\text { Front and Back } \\
\text { Dress Area }\end{array}$ & Knee - Length Dress \\
\hline & $\begin{array}{c}\text { Front and Back } \\
\text { Bodice Area }\end{array}$ & $\begin{array}{c}\text { Short Sleeve High Neck } \\
\text { Top }\end{array}$ \\
\hline & $\begin{array}{l}\text { Asymmetrical } \\
\text { Left Side Front } \\
\text { until Right Arm } \\
\text { on Dress Area }\end{array}$ & Knee - Length Dress \\
\hline & $\begin{array}{c}\text { Front and Back } \\
\text { Lower Skirt on } \\
\text { Long Dress } \\
\text { Area }\end{array}$ & Foot Length Long Dress \\
\hline & $\begin{array}{c}\text { Centre Front } \\
\text { Long } \\
\text { Torso Bodice } \\
\text { until Mid - } \\
\text { Thigh } \\
\text { Area }\end{array}$ & Foot Length Long Dress \\
\hline
\end{tabular}


3.1. Fashion Show Realm of Abstract at Ciputra World Fashion Week 2016 with fashion week theme: Neon Invasion on September 21, 2016 at Ciputra World Surabaya

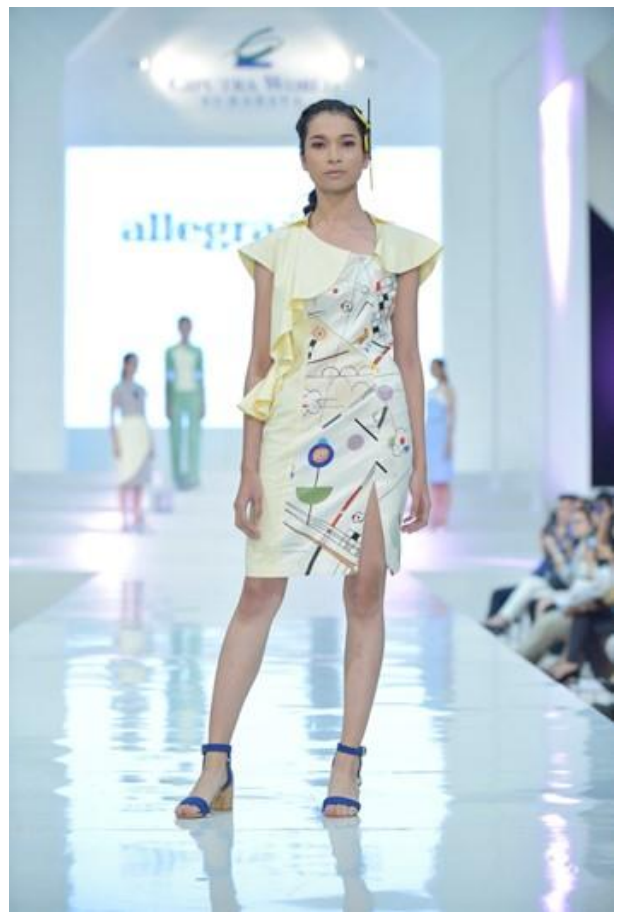

Figure 5. Women's Wear with Satin Velvet of Digital Textile Printing

Motif in combination with Italian Cotton on solid color

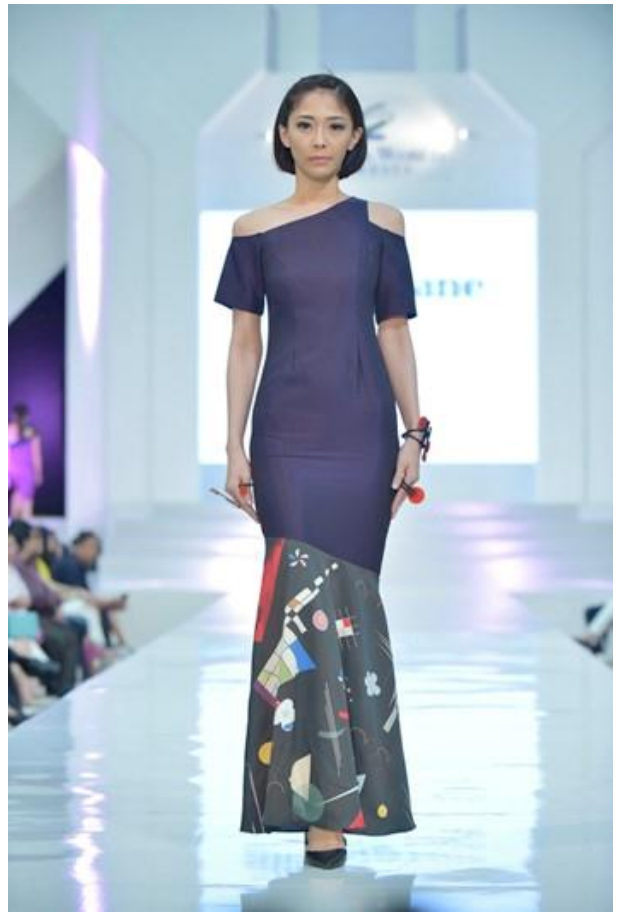

Figure 6. Women's Wear with Satin Velvet of Digital Textile Printing

Motif on lower area in combination with Cotton Metallic Jacquard on upper area

\section{Result and Discussion}

The Capsule Collection of Realm of Abstract have met the satisfaction from fashion clients, curators and media, in which recognized by international fashion mentors in Australia last March 2017, when the creative director has brought some of the collection to receive feedback and opinion from international market. Successful collaboration in between the fashion brand and graphic designer have rewarded, in which achieved many positive opinions for the collection as they were fresh, different, creative with fashion brand's characteristic on the collection looks and graphic designer's signature on art inspired geometric abstract motif as following from the main inspiration from Kandinsky's work.

\section{Conclusion}

The study research and exploration has complied with the need of creative director's aim and successfully achieved from initiation of creative industry collaboration. The successful research of exploration upon Kandinsky's geometrical abstract motif pattern with graphic designer by using stylation method, where converting the original design or form from a source into decorative new form of design, however the trademark and characteristic of the latter's source have not modified thoroughly, the method then applied into geometrical abstract motif pattern for fashion collection. The collection had been shown at other fashion showcase for four times in Surabaya, East Java and also received positive feedback at Australia Awards, where one of Australian Designer's Shop in Melbourne has putting the interest for retail selling Realm of Abstract collection for the shop. Further research succeeding to this study, creative director shall open further exploration with other artist or any other creative industry people with using different type of media, application for the fashion brand's next fashion collection.

\section{ACKNOWLEDGEMENT(S)}

Acknowledgements to Conseva as the brand of the graphic designer in collaboration with fashion brand for geometric abstract pattern design, also The Theme for specially made 
the accessories in order to comply with Realm of Abstract theme of collection.

\section{REFERENCES}

[1] Fashion Snoops. (2016, January 28). Women's Top Forecasted Graphics, Spring Summer 2017. Fashion Snoops Trend Forecaster and Fashion Vignette Trends and Inspirations, Retrieved May 16, 2016, https://fashionvignette.blogspot.co.id/2016/01/trends-f ashion -snoops-womens-top.html

[2] Ogunnaike, N. (2016, December 20). 5 Fashion Trends That Will Be in for 2017 and 5 That Will Be Out. Elle Magazine. Retrieved December 21, 2016, http://www.elle.com/fashion/news/g29249/2017-fashio n-tren ds/

[3] Rachman, F.F. (2016, December 08). Bekraf and BPS launched Statistic Data Creative Economy 2016. Detik Finance, Retrieved June 22, 2017, https://finance.detik.com/berita-ekonomi-bisnis/33660 11/bek raf-dan-bps-luncurkan-data-statistik-ekonomi-kreatif-2 016

[4] Bowles, M, and Isaac, C. (2012). Digital Textile Design. U.K: Laurence King Publishing in association with Central Saint Martins College of Art and Design.

[5] Carden, S. (2015). Digital Textile Printing. U.K: Bloomsbury Academic.

[6] Hallett, C, and Johnston, A. (2014). Fabric for Fashion, The Complete Guide Natural and man-made fibers. U.K: Laurence King Publishing Ltd.

[7] Parsons, J. L, and Campbell, J. R. (2005). Digital Apparel Design Process: Placing a New Technology into a Framework for The Creative Design Process. Clothing and Textiles Research Journal 2005, 1 (2), Volume 22, $88-98$. 